\title{
A (NOVA) ECONOMIA DO PROJETAMENTO: O CONCEITO E SUAS NOVAS DETERMINAÇÕES NA CHINA DE HOJE*
}

Elias Marco Khalil Jabbour ${ }^{1}$

Alexis Toribio Dantas ${ }^{2}$

Carlos José Espíndola ${ }^{3}$ Júlio Vellozo 4

\begin{abstract}
Resumo: O objetivo deste artigo é o de lançar luz sobre as razões pelas quais o conceito elaborado por Ignacio Rangel de "Economia do Projetamento" guarda grandes possibilidades às pesquisas no campo do desenvolvimento econômico chinês. Para tanto buscamos reelaborar o conceito o enriquecendo com novas determinações e critérios de validação que o tornam à altura do alcance do fenômeno em curso na China. Questões como as possibilidades de superação da "incerteza keynesiana", a planificação da "destruição criativa", a soberania monetária e o "pacto tácito de adesão" serão abordadas e tomadas como categorias internas que sustentam, enquanto face empírica, o conceito de Nova Economia do Projetamento. Concluimos afirmando que a Nova Economia do Projetamento se constitui como estágio superior de desenvolvimento do modo de produção dominante à (nova) formação econômico-social que emergiu na China como resultado das reformas econômicas iniciadas em 1978.
\end{abstract}

Palavras-chave: China. Ignacio Rangel. Economia do Projetamento. Socialismo. Desenvolvimento econômico.

\section{THE (NEW) PROJECTMENT ECONOMY: THE CONCEPT AND ITS NEW DETERMINATIONS IN TODAY'S CHINA}

Abstract: The purpose of this article is to shed light on the reasons why Ignacio Rangel's concept of "Projectment Economy" holds great possibilities for research in the field of Chinese economic development. To this objetive, we seek to re-elaborate the concept and enrich with the new determinations and validation criteria that make it up to the scope of the phenomenon underway in China. Issues such as the possibilities of overcoming "Keynesian uncertainty", planning for "creative destruction", monetary sovereignty and the "tacit adhesion pact" will be addressed and taken as categories that support, as an empirical face, the concept of the New Projectment Economy. We conclude by stating that the New Projectment Economy constitutes a superior stage of development of the dominant mode of production internal to the (new) socioeconomic formation that emerged in China as a result of the economic reforms initiated in 1978.

Keywords: China. Ignacio Rangel. Projectment Economy. Socialism. Economic development.

\footnotetext{
* Agradecemos às observações e apontamentos críticos de Simone Deos, Cristiano Capovilla e David Deccache. Quaisquer limites e problemas no artigo é de nossa inteira responsabilidade.

1 Universidade do Estado do Rio de Janeiro, Faculdade de Ciências Econômicas, Rio de Janeiro, Brasil, eliasjabbour@terra.com.br, 0000-0003-0946-1519

2 Universidade do Estado do Rio de Janeiro, Faculdade de Ciências Econômicas, Rio de Janeiro, Brasil, alexis.dantas@gmail.com, 0000-0002-4742-7197

3 Universidade Federal de Santa Catarina, Departamento de Geociências, Florianópolis, Brasil, carlos.espindola@ufsc.br, 0000-0002-5857-6067

4 Universidade Presbiteriana Mackenzie, Faculdade de Direito, São Paulo, Brasil,
} juliovellozo@gmail.com, 0000-0003-0030-0997 


\section{LA (NUEVA) ECONOMÍA DEL PROYECTAMIENTO: EL CONCEPTO Y SUS NUEVAS DETERMINACIONES EN LA CHINA ACTUAL}

Resumen: El objetivo de este artículo es aclarar el concepto elaborado por Ignacio Rangel de "Economía del Proyectamiento" y que ofrece posibilidades para las investigaciones sobre el desarrollo económico Chino. Así, buscamos reelaborar el concepto agregándole nuevas determinaciones y criterios de validación que lo dejan al alcance del fenómeno en curso, en la China. Asuntos como las posibilidades de superación de la "inseguridad keynesiana", la planificación de la "destrucción creativa", la soberanía monetaria y el "pacto tácito de adhesión" serán abordados y considerados como categorías internas que soportan, como fase empírica, el concepto de Nueva Economía del Proyectamiento. Se concluye afirmando que la Nueva Economía del Proyectamiento se constituye como un estadio superior de desarrollo del modo de producción dominante para la nueva formación económicosocial que emergió en la China como resultado de las reformas económicas iniciadas en 1978.

Palabras clave: China. Ignacio Rangel. Economía do Proyectamiento. Socialismo. Desarrollo económico.

\section{Introdução}

Não é novidade aos analistas mais atentos da dinâmica econômica global que o contínuo crescimento econômico chinês consiste no mais impressionante fato da história econômica recente. Por muito tempo, a disputa de narrativas explicativas sobre o desempenho econômico do país ainda foi marcado pelos velhos dispositivos ortodoxos e heterodoxos. De um lado, a abertura econômica a investimentos estrangeiros diretos (IED`s), privatizações, os baixos custos de produção e a alta relação poupança x PIB compunham (e ainda compõem) o quadro explicativo neoclássico. Entre os heterodoxos, o oposto: gradualismo nas reformas, políticas industriais ativas, controle sobre instrumentos do processo de acumulação como a taxa de câmbio e o crédito.

Interessante notar que muitas destas contendas intelectuais acabam encontrando algum termo diante de algumas combinações de eventos, como a que presenciamos nos dias de hoje. Fica insustentável à ortodoxia a manutenção de seus pressupostos diante da capacidade de reação chinesa à pandemia do Covid-19 onde se evidenciou a existência de uma série de capacidades estatais que estariam longe do alcance analítico que pressupõe equilíbrio de fatores, setor privado à dianteira do processo de acumulação e Estado "cada vez menor" 5 . Não bastasse

\footnotetext{
${ }^{5}$ Lardy (2018) após sustentar por décadas que as reformas chinesas eram "pró-mercado", passa a perceber a reversão desta tendência. Com visão das reformas semelhante ao de Lardy, Naughton (2017) após perceber avanço do Estado chinês sobre os controles dos fluxos de renda, lança a questão sobre a possibilidade de a China ser socialista. Gabriele (2020) expõe o caso chinês, a partir
} 
esse poderoso golpe da realidade, o presidente dos EUA declarou guerra comercial à China, justamente - dentre outros motivos - por práticas de "dumping cambial", subsídio a grandes empresas estatais e institucionalização constante de reserva de mercado.

De forma sucinta, Rodrik (2020) coloca o debate em seus devidos termos, conforme segue:

(...) we must recognize that a mixed, state-driven economic model has always been at the root of Chinese economic success. If one-half of China's economic miracle reflects its turn to markets after the late 1970s, the other half is the result of active government policies that protected old economic structures - such as state enterprises - while new industries were spawned through a wide array of industrial policies.

Apesar de ladearmos com opiniões heterodoxas, acreditamos ser necessária a superação desta falsa dicotomia entre Estado e setor privado no processo de desenvolvimento. O trabalho de Mazzucato (2014) é interessante, também, como demonstração deste problema político e ideológico e que invade a seara da metodologia científica. Esse problema metodológico é mais grave na analise de uma realidade como a chinesa onde a fronteira entre as diferentes formas de propriedade é muito tênue dado a capacidade de controle direto e indireto do Estado sobre todo o tecido produtivo e financeiro do país - fruto de constantes ondas de inovações institucionais (Jabbour e Paula, 2020) que alçaram a patamares superiores a capacidade de controle estatal sobre os gânglios vitais da economia do país ${ }^{6}$. A nós é exatamente esta percepção - ao lado do surgimento de novas e superiores formas de planificação econômica - que nos faz levantar a hipótese sobre a existência de um déficit teórico no que tange a apreensão de uma realidade econômica em constante mutação como a chinesa7.

O avançar da China a novos aportes em matéria de planificação econômica é perceptível na rapidez com que o território foi transformado, sobretudo na última década. Esta transformação territorial, mediada por grandes pacotes fiscais voltados a investimentos em infraestruturas, ocorreu pari passu ao desenvolvimento de novos

de 1978, percebendo-o como uma transição de uma economia centralmente planificada a uma forma de planificação compatível ao mercado. Jabbour e Dantas (2017 e 2018) desenvolvem a noção de "recolocação estratégica do Estado" como forma de indicar o crescente papel qualitativo do Estado após 1978.

6 Pesquisas recentes fizeram apontamentos interessantes e acertados sobre a elevação da participação e controle estatal sobre a riqueza e os fluxos de renda na China. Piketty et al (2017), Naughton (2017) e Nogueira et al (2019) têm conclusões semelhantes demonstrando que o Estado chinês controla atualmente cerca de $30 \%$ da riqueza produzida no país. De forma contraditória, atualmente o Estado chinês conta com uma capacidade muito maior de intervenção sobre a realidade do que o tinha no final da década de 1970.

7 Segundo Rangel ([1956] 2005, p. 237): Toda a problemática econômica muda quando passamos de uma etapa a outra, mudando também o equipamento científico adequado. 
esquemas de divisão social do trabalho. Simultaneamente a China tanto logrou alcançar a fronteira tecnológica em campos como a plataforma $5 \mathrm{G}$ e o Big Data quanto tem planificado um dramático movimento onde a agricultura já se apresenta como um ramo da indústria, a caminho da especialização produtiva e certa superação de formas familiares de organização da produção ${ }^{8}$. No plano mais conjuntural, a presente pandemia do Covid-19 apresentou ao mundo a existência de uma verdadeira "economia de prontidão" demonstrada pela grande capacidade de contenção interna da pandemia (auxiliada por rápidos processos de reconversão industrial) e a já iniciada recuperação econômica do país ${ }^{9}$.

Nosso ponto de inflexão em relação aos postulados dominantes, ortodoxos e heterodoxos, está na percepção de que a China tem adentrado a uma dinâmica de acumulação onde a superação de restrições dos mais variados tipos e da incorporação à economia real de novos aportes tecnológicos abriram condições tanto para elevar o grau de racionalidade sobre o processo produtivo e consequentemente transformar a economia chinesa em uma verdadeira máquina de construção de grandes bens públicos e, mesmo, de valores de uso. A esse estágio superior alcançado pelo "socialismo de mercado" convencionamos chamar de "Nova Economia do Projetamento"10. A alusão ao conceito desenvolvido por Rangel ([1959] 2005) não é fortuito na medida em que observamos na China algumas das regularidades percebidas pelo mestre maranhense tanto na URSS quanto nos países capitalistas centrais sintetizadas nas grandes possibilidades anexas à humanidade tanto do planificação central no mundo socialista quanto no papel do Princípio da Demanda Efetiva e dos mecanismos de "socialização do investimento" no mundo capitalista.

O objetivo deste artigo é o de lançar luz sobre as razões pelas quais o conceito elaborado por Ignacio Rangel de "Economia do Projetamento" guarda grandes possibilidades às pesquisas no campo do desenvolvimento econômico chinês. Para tanto buscamos reelaborar o conceito enriquecendo com as novas determinações e critérios de validação que o tornam à altura do alcance do

\footnotetext{
8 A mediação de um problema de superpopulação agrária que não pode se transformar em superpopulação urbana, apesar de carregar inúmeras contradições de ordem política e social, é algo que tem sido levado a bom termo pela governança do país. O futuro da figura do camponês em um país onde mais de 500 milhões de pessoas ainda estão, total ou parcialmente, ocupadas em atividades agrícolas é objeto de grandes disputas políticas no país. Sobre isto ler Zhan (2020). A nosso ver trata-se de uma questão a ser pensada e solucionada de forma planificada.

9 Projeções do Banco Mundial apontam crescimento econômico de 1\% para 2020 e de $6,9 \%$ em 2021.

${ }^{10}$ Considerações teóricas iniciais sobre a Nova Economia do Projetamento podem ser encontradas em Jabbour, Dantas e Espíndola (2020).
} 
fenômeno em curso na China. Metodologicamente, trata-se de uma análise aprofundada do conceito rangeliano da Economia do Projetamento, combinada com outros referenciais teóricos e com os dados quantitativos coletados junto ao Banco Mundial, National Bureau of Statistics (China) e do Global Wage Report (International Labour Organization).

O presente artigo, além desta introdução, será composto por outras duas grandes seções. Na seção 2 resgataremos a essência original do conceito de "Economia do Projetamento" surgida no final da década de 1950. Na seção 3 a intenção será o de demonstrar a validade teórica a este conceito na atualidade. Para tanto serão expostas alguns elementos novos, dentre tais o papel do setor público (GCEE e grande finança estatal) na economia no sentido de criar regularidades que sustentam a superação da incerteza keynesiana, a planificação da "destruição criativa", o pleno exercício da soberania monetária e o que chamamos de "pacto tácito de adesão"11 em particular como eixos de sustentação a uma economia que se move racionalmente no sentido de construção de grandes bens públicos; algo completamente diverso tanto do "keynesianismo militarizado" praticado pelos EUA quanto da própria dinâmica financeirizada que comanda o capitalismo internacional. Ao final apresentaremos algumas conclusões entre as quais a que versa sobre a possibilidade de a Nova Economia do Projetamento, enquanto elevação do papel da razão sobre o processo de produção, abrir possibilidades para novos aportes teóricos capazes de explicar a China.

\section{0 resgate de um conceito original}

O resgate do conceito de "Economia do Projetamento" é uma necessidade diante dos desafios que a atual estágio de desenvolvimento chinês impõe à ciência econômica. Noções como "equilíbrio geral" e, mesmo, o conceito de Princípio da Demanda Efetiva são imprecisos como meios explicativos. O primeiro por ser anticientífico e a-histórico ${ }^{12}$, afinal o processo de desenvolvimento é fruto de "tensões, desproporções e desequilíbrios" (Hirschman, 1958, p. 118); "salto ininterrupto de um desequilíbrio a outro" (Rangel, 1954 [2005], p. 41); o segundo

11 O "pacto tácito de adesão" seria a contraparte sob forma de uma sociabilidade de novo tipo correspondente ao estágio de desenvolvimento das forças produtivas na China e em relação à Nova Economia do Projetamento.

12 Do ponto de vista hegeliano podemos classificar a terminologia do "equilíbrio geral" como uma simples representação. Nada além de uma representação mental, unilateral, da realidade. Não atingiu o status de conceito. 
pelo fato de o próprio Princípio da Demanda Efetiva ser algo corrente na China, não somente um meio ativado na fase descendente do ciclo. É válido, inclusive, propor neste resgate do conceito em tela a transformação da demanda efetiva como regularidade sob forma de uma já citada "economia de prontidão", uma vez que só o é dado o papel proativo da proeminência do Estado sob os núcleos produtivo e financeiro do país. A "Nova Economia do Projetamento" funciona em permanente Estado de efetivação de demanda.

Ao caso chinês, a perda de validade de algumas noções consagradas pelos dois polos do debate de ideias no campo das ciências econômicas impõe uma reconceituação daquele processo. O conceito de "Economia do Projetamento" é adequado na medida em que dá sentido à existência na realidade, "uma unidade ideal mediada de seus momentos particulares" (Hegel, 1905 [2001], p. 125). Ora, no concreto os grandes projetos passam a ser o próprio sentido da realidade sensível, elo de conexão entre diferentes fases de um mesmo processo histórico; guarda diversidade na medida em que seus instrumentos institucionais fundamentais não serem únicos e de propriedade de uma única unidade de análise. É característico de um momento histórico onde o Estado é a própria regularidade que confere sentido ao próprio projeto, se manifestando - na presente quadra histórica - em sua plenitude no todo de um modo de produção específico, o socialismo. Mas como unidade do diverso, contém também os germes da exceção capitalista como gestada no caso alemão ${ }^{13}$.

O humanismo expressa-se na dialética que se traduz em teoria a partir da história. Neste sentido, ainda no campo da filosofia e em tempos em que a Economia tem sido reduzida a uma ideologia de cunho reacionária e braço matemático do irracionalismo filosófico, este construto intelectual de Ignacio Rangel é fruto, segundo Castro (2014, p. 222), de:

(...) uma antropologia filosófica que pensa o homem em sua afirmação racional, sem fetiches e senhor de seu destino. A crença no progresso e traços prometeicos na relação com a natureza completam uma visão que tem raízes no racionalismo clássico. O socialismo não é um fato fortuito, é o devir esperado que está sendo construído historicamente

\subsection{Os estertores históricos do conceito}

Ressaltamos que não propomos uma novidade em matéria de abordagem teórica/metodológica. Nossa proposta é resgatar um veio dialético de interpretação

${ }^{13}$ Sob nosso ponto de vista a Alemanha é um caso, uma forma de "Economia do Projetamento" de tipo capitalista. 
que se perdeu ao longo do tempo e foi interrompido história. Perdeu-se ao longo do tempo na medida em que o próprio Rangel reconhecia nesta construção conceitual sua principal obra (Castro, 2014, p. 222; Santos, 1997). Foi temporariamente interrompido pela história com o desaparecimento da URSS e a transformação da financeirização na dinâmica de acumulação predominante e com o ressurgimento, nos Estados Unidos, do antigo keynesianismo militarizado da Alemanha nazista. Mas retoma validade teórica, com novas determinações, na transformação da economia chinesa em uma já referida máquina de construção de grandes bens públicos voltados à superação das imensas contradições de décadas de processo ininterrupto de crescimento econômico.

A face do sistema econômico internacional muda de fisionomia em meio a um processo histórico aberto pelas mudanças institucionais ensejadas com a inauguração da planificação econômica em larga escala na Rússia soviética, o aparecimento keynesianismo não-militarizado presente na reconstrução europeia no pós-1945 e o papel do capital financeiro no suporte de grandes projetos e bens públicos anexos ao processo de urbanização e seu braço público sob os auspícios do Welfare State. A Economia do Projetamento, em Rangel, era a modus operandi que surgia da grande convergência entre os três eventos citados, tendo sua expressão mais acentuada na União Soviética dos planos quinquenais. Em retrospectiva histórica tanto o socialismo quanto o capitalismo guardavam muito da racionalidade pela qual gritava a humanidade após a tragédia de duas grandes guerras.

A capacidade de regular o sistema financeiro e o estabelecimento de um sistema de câmbios fixos restringia a livre ação da lei do valor, abrindo margem à possibilidade de execução de grandes projetos geradores de efeitos multiplicadores a cada economia nacional. No campo socialista a socialização dos principais meios de produção, a formação maciça de profissionais no campo das engenharias e matemática e a proliferação da teoria e prática da planificação possibilitaram a formação em menos de vinte anos de uma base material que derrotou a máquina de guerra nazista e lançou o primeiro ser vivo (1957) e, também, o primeiro humano ao espaço (1961). Sob este prisma, uma leitura atenta de "Elementos de Economia do Projetamento" será suficiente para, nas palavras de Castro (2014, p. 206), perceber que: 
dos analistas que, naturalmente, são de diferentes escolas teóricas e de diferentes profissões.

A restrição à ação da lei do valor, a possibilidade da utilização de grandes pacotes fiscais (capitalismo) ou mobilização de mais-valia apreendida pelo Estado (socialismo) coloca para Rangel a necessidade de resposta ao papel do projeto em uma sociedade com baixa intensidade de ação mercantil. Qual o elemento específico da economia do projetamento? Qual sua métrica de funcionamento? Qual seu objetivo e, por conseguinte, o que passa a servir de base ao cálculo econômico?

A resposta a estas questões podem ser a fronteira entre a resposta ou a não resposta diante do nível de racionalidade empregada no movimento e no, devir esperado, de uma economia do porte da China.

\subsection{O conceito como forma histórica}

De forma sucinta, a prática do projetamento pode ser considerada a resposta histórica ao empiricismo do empresário privado e dos resultados econômicos baseados nas alternativas mercantis, da ditadura do consumidor e expressas em termos de rentabilidade da empresa (Rangel, 1956 [2005], p. 254). Neste sentido, a "Economia do Projetamento" é a superação tanto do individualismo metodológico quanto do curto-prazismo keynesiano. O projeto ganha um sentido mais amplo do que um complexo caráter técnico e microeconômico. No pós-guerra, o projetamento - visto em totalidade concreta com o planejamento - ganha status prática científica que buscava, em grande medida, substituir as forças do mercado. No tempo presente, a "Nova Economia do Projetamento" compreende unidade entre seu conteúdo tanto antitético quanto alternativa objetiva à dinâmica financeirizada do capitalismo.

Grandes pistas do que seria exposto com mais peso e conteúdo em 1959 foram esboçados em "Desenvolvimento e Projeto", de 1956. Por exemplo, Neste livro, Rangel lança a necessidade de se reformular as condições de se projetar dadas as diferenças de dimensões e interesses envolvendo o projetamento feito por um Estado em comparação com o feito pelo empresário privado, marcantemente empiricista e pautados pela curta formulação da relação entre custos e benefícios visando maximizar seus próprios investimentos. A ciência proposta por Rangel recoloca os termos desta relação propondo, em suas palavras (Rangel, 1956 [2005], p. 257): 
(...) os conceitos de custo e benefício devem ser reformulados, no sentido de que comportem não apenas o custo e o benefício diretos, mas também os indiretos. Nosso critério deve ser o custo benefício para a sociedade, não para a empresa.

A interposição do custo benefício social em detrimento do empresarial implica em métodos de correção de critérios às empresas. Uma operação nada fácil, à época de Rangel, nem tampouco hoje. Mas ao que nos interessa atualmente (a evolução conceitual), o mestre maranhense ainda é cirúrgico ao expor que no capitalismo esse método de correção poder ser guiada, pela visão do empresário privado, pela taxa de juros, enquanto que o planejador soviético recorre ao aumento da produtividade do trabalho como métrica (Rangel, 1956 [2005], p. 257) - o mesmo critério utilizado pelos planejadores da SASAC (State-owned Assets Supervision and Administration Commission of the State Council) como método de correção aplicado às 97 GCEE que atuam sob seu controle. Trata-se de um critério estratégico ao processo de catching-up chinês. Algo que nos países capitalistas tem relações mais próximas de critérios envolvendo demanda efetiva, por exemplo.

A quem lê os escritos de Rangel no final da década de 1950 sobre a temática do planejamento e do projetamento sem uma visão de fundo sobre o grande debate que travou contra cepalinos e keynesianos, pode julgar que as palavras dele tinham caráter puramente "técnico". Porém, a grande verdade é que Rangel estava travando uma batalha em torno do próprio conceito de planejamento. Para Rangel a questão não era buscar soluções técnicas e curtoprazistas para reverter tendênicas históricas inerentes à divisão social do trabalho. As palavras de Pedrão (2014, p. 86) são esclarecedoras para colocar em contexto a construção do conceito por Rangel:

\begin{abstract}
A necessidade de construir uma visão brasileira do processo da economia se estenderia à visão do processo da teoria. Em seus primeiros textos Rangel se colocou na linha de frente da crítica da teoria do desenvolvimento patrocinada pelas Nações Unidas. Não se trata necessariamente de escrever uma teoria, mas de tratar teoricamente os problemas da realização da desigualdade patrocinada pelo imperialismo.
\end{abstract}

A forma histórica com a qual o projetamento se defronta e se desenvolve (na China de hoje) é justamente espelhada nas soluções encontradas diante, não somente as contradições internas ao seu processo de desenvolvimento, mas principalmente com a possibilidade de romper com a acima citada "desigualdade patrocinada pelo imperialismo", tendo a dependência tecnológica para com os EUA objetivo a ser alcançado. Vivemos a época onde uma guerra comercial e tecnológica 
contra a China está declarada pelo imperialismo ${ }^{14}$. A elevação da capacidade de projetar grandes programas internos de forma autônoma está na ordem do dia dos acontecimentos.

\subsection{O conceito e a "utilidade"}

Dada a natureza da obra de Ignacio Rangel não existem dúvidas que houve uma feliz tentativa de construção de uma teoria compreendendo as transformações que ocorriam tanto no capitalismo quanto, e principalmente, no seio da economia planificada soviética (Castro, 2014, p. 206) no final da década de $1950^{15}$. O livro "Elementos de Economia do Projetamento" é uma madura síntese de ideias e impressões do autor sobre as novas determinações da economia internacional em seu tempo. Rangel absorve de forma criativa a noção kantiana ${ }^{16}$ para quem as ciências teriam uma dupla dinâmica evolutiva. Uma de caráter nomenal (ligado diretamente à história) e outra, mais prática, fenomenal ${ }^{17}$.

Observando o século $X X$, podemos perceber que a evolução histórica e as novas formas de produzir e planificar a produção de mercadorias necessitavam de teorias mais capazes de explicar as novas ocorrências verificadas na URSS e nos países capitalistas centrais. O projetamento, neste sentido, estava amadurecendo enquanto nômeno - para sistematização e elaboração. É síntese de múltiplas determinações, “(...) é, ao mesmo tempo, teoria e prática macro e microeconomia; é

\footnotetext{
14 Jabbour, Dantas e Espíndola (2020) evidenciam a "Nova Economia do Projetamento" com os novos aportes em matéria de fronteira tecnológica que têm na China um de seus participes.

${ }^{15}$ Rangel via paralelismos entre os modelos de planejamento da URSS e dos EUA. A Rangel ambas poderiam se constituir como "modelos fechados" dado o fato de suas operarem sobre economias continentais. Ao primeiro caso, Rangel (1956 [2005], p. 260) classificava "como um verdadeiro esforço de desenvolvimento" voltado à integração de milhares de trabalhadores ocupados em atividades agrícolas à "economia nacional" (equivalente socialista da "economia de mercado"), enquanto que a economia dos EUA, por enfrentar outro tipo de problemática, o planejamento tem apenas a tarefa de garantir emprego remunerado a toda população remunerada Rangel (1956 [2005], p. 261).

$16 \mathrm{O}$ amigo e filósofo Cristiano Capovilla nos lembra que ao atribuir um "caráter nomenal (ligado diretamente à história) e outra, mais prática, fenomenal" as análises científicas, Rangel está na verdade contrariando a teoria kantiana, uma vez que está admitindo o conhecimento do "nômeno", da coisas em si, da essência, o qual ele chama de "história". Enfim, certamente Rangel se apropria de terminologias kantianas, mas não seu conteúdo. Kant ainda não absorveu em suas formulações o conceito de história; o "tempo" ainda é uma categoria a priori, subjetiva. A história só vai ser incorporada à racionalidade com Hegel.

17 Tendo como pressuposto esse duplo caráter evolutivo da ciência econômica, os limites de fronteira com os desígnios da "economia vulgar", tornam-se mais claros. Para Rangel ([1956] 2005, p. 204205): O conceito vulgar admite explicitamente apenas a evolução fenomenal da economia. Cada nova teoria surge como resultado de uma representação mais precisa da realidade transcendente, a qual, explicitamente, permaneceria sempre igual a si mesma. Assim a análise smithiana seria, em comparação com a fisiocrática, apenas uma representação mais perfeita, que considera certas facetas que Quesnay e seus amigos uniria a análise neoclássica à clássica, a keynesiana à neoclássica.
} 
teoria e prática; é apreciação do particular no geral, do concreto no abstrato, e verificação do abstrato no concreto" (Rangel, 1959 [2005], p. 362).

O autor parte, de forma destemida e com boa dose de ecletismo a uma grande empreitada intelectual. A percepção de quem lê e estuda esta obra, e já familiarizado com as elaborações de fronteira rangelianas, que o projetamento - em Rangel - se constituía em um novo modo de produção que surge das regularidades em comum entre as economias soviética e capitalistas centrais. Logo, a questão sobre o nomeno deste novo modo de produção é imediatamente apresentada por Rangel desde o início do livro: a utilidade. Suas categorias fundamentais continuam sendo os já citados mais acima, o custo e o benefício. Segundo Rangel (1959 [2005], p. 367), custo e benefício são:

(...) abstrações úteis para o encaminhamento da solução de problemas implícitos, (...). Toda a teoria do projetamento não passa, em última instância, de um esforço para precisar estes dois termos, para com eles construirmos uma razão (...)

Eclético, sem deixar de ser historicista, Rangel abdica do dogmatismo para colocar no centro da problemática do projetamento a utilidade. O modo de produção que ele propõe existência palpável é algo guiado de forma consciente e racional; é voltado à construção de valores de uso. A utilidade é a nova base para o cálculo econômico. Seus meios principais são o plano e o projeto. A utilidade é estendida, conforme já posto acima, como o nômeno de um novo momento histórico ${ }^{18}$. Segundo Castro (2014, p. 208):

Por que construir a categoria utilidade se afastando da categoria valor? $\mathrm{O}$ valor como nômeno e a categoria teórica valor como fenômeno estão relacionados a uma economia mercantil. A economia do projetamento, que começa a tomar corpo, é o devir, está relacionada a outro momento histórico, outro nômeno, portanto ${ }^{19}$. A utilidade está relacionada com essa problemática.

Oportuno notar que ao manejarmos o conceito de utilidade estamos trabalhando sob uma outra perspectiva ${ }^{20}$, algo muito distante da maximização da utilidade muito cara aos neoclássicos que o definem como uma resposta do indivíduo confrontado com a concorrência e o mercado - logo, portador de uma

\footnotetext{
18 Rangel (1959 [2005], p. 367), coloca a utilidade em conceitos aristotélicos, quando define a riqueza como a qualidade que têm certas coisas de serem úteis à sociedade humana (...). A utilidade das coisas é uma relação entre elas e a sociedade ou as pessoas. As coisas são úteis quando o homem pode satisfazer suas necessidades por meio delas(...)

${ }^{19}$ Leia-se, socialismo, como o novo momento histórico que tem na utilidade seu nômeno.

20 Observando historicamente, essa nova métrica à seleção de técnicas e formas de alocar os recursos é muito diferente do capitalismo onde a produção de valores é regulada pelo mercado através do valor, seja ele explicado pelo trabalho, para os clássicos, ou pela utilidade marginal, para os neoclássicos (Castro, 2014, p. 208).
} 
subjetividade presa à parâmetros, do ponto de vista marxiano, do último estágio préhistória da humanidade (capitalismo). A utilidade aqui é posta, inclusive como separada da categoria valor justamente por ser o nômeno de um momento histórico em que a criação de valor vai deixando de ser uma necessidade primária do sistema, fruto do nível de desenvolvimento das forças produtivas alcançadas pelo o que Marx chamava de setor produtivo da economia ${ }^{21}$. Resumindo: o projeto tem o papel de produzir utilidade onde a síntese da relação custo/benefício é sintetizada sob a forma de riqueza a ser apreendida de forma social.

\subsection{O Projetamento e os dois sentidos estratégicos da razão}

Ignacio Rangel em sua "ciência do projetamento" estava a sistematizar a razão e sua expressão no processo de reprodução social, sendo a processo de produção (de utilidades) não somente seu próprio núcleo, mas também seu campo privilegiado de ação. O projetamento é instrumento de um Estado guiado pela ciência em todos os seus matizes. Seu sentido estratégico - em uma formação econômico-social complexa é a difícil combinação de catching-up tecnológico, acumulação primitiva socialista ${ }^{22}$ e com uma "macroeconomia do pleno emprego". É este sentido que Rangel, também, aponta em sua obra. Voltemos novamente a ela.

Em capítulo específico onde Rangel trata de forma direta da "macroeconomia do projeto", transparece a evidente preocupação da ação do projetamento em economias com tendência ao desemprego que a seu tempo eram de caráter capitalista, mas que na atualidade tem muita validade a economias de mercado socialistas como a China e o Vietnã onde a planificação é orientada pelo mercado. Antes desta importante capítulo, ao tratar das "assimetrias básicas do projeto", ele prepara o leitor a uma verdadeira "desfetichização do capital".

Assim o faz quando trata do papel do capital no processo de produção e as razões pelas quais o detentor do capital detém o comando de todo processo produtivo. Ao que aparentemente podem ser vistas como referências soltas no que

\footnotetext{
${ }^{21}$ Marx, como Smith, separava todas as atividades econômicas entre produtivas e improdutivas, sendo as produtivas relacionadas com os setores de bens e equipamentos geradores de valor enquanto as atividades improdutivas estão relacionadas à manutenção da ordem social. A nosso ver o desenvolvimento recente do capitalismo deve nos obrigar a rever estes dois conceitos. Por outro lado, estendemos, ao fim de compreender o socialismo em nosso tempo, ao setor improdutivo aquele apontado por Marx em "A Crítica ao Programa de Gotha" (1891) como parte dos chamados "fundos de consumo" para onde deveriam ser dirigidos crescentes excedentes do setor produtivo da economia. Tais fundos de consumo teriam, hodiernamente, expressão no desenvolvimento dos setores como de educação, saúde, cultura, esporte, recreação etc.

22 Cheng (2020) explora de forma criativa a teoria, elaborada pelo economista russo Evgeni Preobrazhenski, da "acumulação primitiva socialista" para confrontar as hipóteses correntes sobre o caráter capitalista do desenvolvimento recente chinês.
} 
cerne a relação entre o detentor do fator capital e a problemática da imobilização, se trata de uma preocupação latente de Rangel com as condições de vida e consumo dos trabalhadores. Ironizando a célebre frase de Keynes, ao referir ao papel do aumento do capital, conforme segue (Rangel, 1959 [2005], p. 433):

\begin{abstract}
Esta, já observamos, é a única forma possível de crescimento do produto per capita no longo prazo. Não pode haver crescimento econômico sustentado e intenso senão por esse meio. Mas para usarmos o dito chistoso de Keynes, "no longo prazo estaremos todos mortos". Muitas vezes, o economista pode confrontar-se com a circunstância de que parte maior ou menor da mão-deobra do seu país ou região em condições de trabalhar está reduzida á inatividade forçada, total ou parcial. Nesse caso a estratégia geral do desenvolvimento deve ajustar-se a esta circunstância e o projetista, como tático do desenvolvimento, deve ajustar seus critérios a essa circunstância ${ }^{23}$.
\end{abstract}

Neste sentido chegamos ao primeiro sentido estratégico da razão: a superação do desemprego como circunstância, seja permanente ou não. Eis um traço prometeico da proposta rangeliana. Neste aspecto eleva-se o prestígio e a responsabilidade do projetista, como "tático do desenvolvimento". Sobre esta responsabilidade, Rangel ([1959] 2005, p. 405) chama a devida atenção:

O projetista, ao decidir entre duas técnicas, deve sentir-se agente da sociedade, o que exige que nada aceite sem exame. Sua ação deve ser orientada por um plano-mestre geral (...) e esse plano será diferente segundo haja ou não desemprego. A ele deve subordinar-se toda a sua ação (...). Se há desemprego, deve trabalhar para induzir o emprego pleno; alcançado este, deve buscar a gradual retirada do trabalho dentre os fatores de produção e o projetista, como tático do desenvolvimento, deve ajustar seus critérios a essa circunstância ${ }^{24}$.

Sobre o segundo sentido estratégico da razão, situamos o papel e a percepção do desequilíbrio como parte fundamental da "marcha no sentido da abundância” (Rangel ([1959] 2005, p. 421). A prática do projetamento como altar máximo da razão ganha contornos de elo entre o salto de um ponto de desequilíbrio a outro, marca registra do processo de desenvolvimento. A razão é encontrada no que Rangel ([1959] 2005, p. 378) chamava de "convite à mudança":

(...) os efeitos de cada projeto são, ao mesmo tempo, globais e específicos. É através de mudanças introduzidas no modo de operação de todas as unidades preexistentes, que se alcança o efeito global, e essas mudanças representam, para todas e cada uma das empresas do sistema, um "convite à mudança".

Uma leitura mais atenta do opúsculo rangeliano poderá nos levar a interessantes conclusões no que cerne o alcance da própria razão no processo de

\footnotetext{
${ }^{23}$ Negritos nossos

${ }^{24}$ Castro $(2014$, p. 219), dá um interessante exemplo que relaciona a desfetichização do capital e o que chamamos de "primeiro sentido estratégico da razão": Para fins de plena utilização de mão de obra, na macroeconomia da Economia do Projetamento, a alocação de recursos - via plano - pode ocorrer sem elevação da técnica.
} 
produção. Exemplo disso está na própria programação do desequilíbrio, encetando uma outra - mais sofisticada e mais próxima do tempo presente - definição do próprio processo de desenvolvimento: uma processo longe de buscar um permanente ponto de equilíbrio. Ao contrário. Trata-se de um processo que ocorre a partir da introdução de causas de novos desequilíbrios de natureza especial. Ao autor, as mudanças (desequilíbrios), em última instância, assumem duas formas, uma de ordem tecnológica e outra mais relacionada à distribuição dos recursos sociais entre as diferentes indústrias ([1959] 2005, p. 379).

De forma menos abstrata, podemos conceber que o projeto chega ao planejamento via saltos de um desequilíbrio a outro até o momento em que a tecnologia se transforma em instrumento fundamental à atração que a razão pode exercer sobre o processo produtivo. Mantém-se uma lógica fundamental do processo de desenvolvimento: com a técnica elevando a patamares superiores a divisão social do trabalho, mudando - assim - a face do sistema.

\section{A China e as novas determinações da Economia do Projetamento}

Teorias, conceitos e categorias são construções históricas - em grande medida, datáveis. Com a "Economia do Projetamento" originalmente concebida por Rangel não é diferente. Seu núcleo não muda, ou seja, a possibilidade de uma economia superar a produção de valores (de troca e de uso) regulado pelo mercado por outra, onde a utilidade, precedida pela produção, racional e consciente, em massa de valores de uso, passa a ser a reguladora do sistema. A China é a sociedade no mundo de hoje onde esta transição ocorre. O papel do analista passa a ser o de identificar as regularidades e determinações em marcha que sustentam nossa hipótese.

\subsection{O projetamento, a incerteza keynesiana e a "destruição criativa"}

Rangel é explícito ao afirmar sobre o desemprego como uma circunstância inerente ao capitalismo, logo o projetamento - e os projetistas - devem levar esta circunstância em máxima consideração. A questão da incerteza como elemento que norteia a tomada de decisão do investidor foi devidamente incorporada à teoria econômica por Keynes e Knight ${ }^{25}$. Trazemos à tona esta questão justamente por se

\footnotetext{
${ }^{25} \mathrm{Na}$ verdade, a introdução da incerteza no arcabouço teórico das ciências econômicas foi um salto de qualidade em relação à Economia Política clássica, para quem a economia operava com "pleno emprego de fatores". Sobre este salto teórico ler Stohs (1980).
} 
tratar do maior obstáculo à conformação de uma economia voltada à superação do desemprego enquanto circunstância. A centralidade deste conceito a Keynes, a à própria realidade do capitalismo - tornando-se parte de sua essência, é muito bem sintetizada por Jespersen (2009)26:

Keynes developed his understanding of uncertainty throughout his economic writings. A Treatise on Probability from 1921 was mainly about individual decision making in anuncertain environment dependent on what information was available. Through the 1920's Keynes got a vast number of practical experiences from his work in the financial sector, which was a great source of inspiration to develop his theory of 'liquidity preference' (...). During the early 1930's he started to doubt that a realistic macroeconomic analysis could be kept within the boundaries of a closed model analyses. Because, if uncertainty plays a significant role at all stages of decision making, then coordination failures are unavoidable in this ever changing macroeconomic environment.

Evidente que o socialismo é um estágio de desenvolvimento humano onde o desemprego deverá tender ao desaparecimento em meio a tensões entre a introdução de novas técnicas, seus impactos e a criação de condições políticas e institucionais que permitam a operação do Princípio da Demanda Efetiva em um patamar mais elevado, superando sua temporalidade de ação estendendo-a a um estado permanente em que razão humana deverá se concentrar e operar a tensão entre a técnica e o utilização de todo trabalho vivo disponível. Voltando a Keynes e a incerteza, o papel do Estado através de política monetárias e fiscais, se ampliaria no sentido de superar as deficiências de curto prazo do setor privado (Carvalho, 2015, p. 45), sendo assim uma questão é legítima: quais mecanismos institucionais podem ser lançados mão no sentido da superação da citada circunstância? Em que medida a Nova Economia do Projetamento e o caso em curso na China responde a esta questão fundamental ao progresso humano?

A resposta inicial a esta questão está na percepção da historicidade do setor privado como setor de vanguarda do processo de acumulação. A incerteza, e sua ampliação em tempos de financeirização, só pode ser passiva de controle através de políticas de socialização do investimento permeadas por controle da conta de capitais e ampla repressão financeira. Porém uma outra dimensão é fundamental: a decisão do investimento estaria subordinada a interesses privados muito bem

26 Tradução: Keynes desenvolveu sua compreensão da incerteza ao longo de seus escritos econômicos. Um Tratado sobre Probabilidade de 1921 tratava principalmente da tomada de decisões individuais em um determinado ambiente, dependendo das informações disponíveis. Durante a década de 1920, Keynes obteve um vasto número de experiências práticas de seu trabalho no setor financeiro, que foi uma grande fonte de inspiração para desenvolver sua teoria de "preferência pela liquidez" (...). Durante o início dos anos 1930, ele começou a duvidar que uma análise macroeconômica realista pudesse ser mantida dentro dos limites de uma análise de modelo fechado. Porque, se a incerteza desempenha um papel significativo em todos os estágios da tomada de decisão, então as falhas de coordenação são inevitáveis neste ambiente macroeconômico em constante mudança. 
elencados e discutidos por Kalecky (1943). A decisão do investimento como atributo do empresário privado tem consequências políticas muito bem conhecidas. Aliás, a decisão do investimento não pode se resumir a uma atitude econômica diante da realidade. Trata-se de uma atitude política, principalmente. A estatização dos meios estratégicos de produção tem justamente o papel de retirar da burguesia esse imenso poder político que se encerra na decisão de investir ou não.

Porém, em uma formação econômico-social como a que tem se desenvolvido na China, onde o Estado controla os meios estratégicos de produção e financiamento, o setor privado dependendo dos efeitos de encadeamento gerados pelas GCEE e a pressão por geração de milhões de empregos anuais, a possibilidade de superação da incerteza keynesiana deve ser analisada em conjunto com o papel da planificação sobre outro fenômeno: a destruição criativa. De um lado inovações institucionais garantem compromissos de continuidade do processo de desenvolvimento, por outro o "projeto" deve ser acompanhado pelas possibilidades de abertura de novos campos de acumulação na economia. Traduzindo: o sentido do projetamento pode se sentir no aumento da produtividade do trabalho em relação direta com a elevação do consumo via ganhos salariais combinando diminuição e possibilidade de superação da incerteza keynesiana e a planificação da destruição criativa - via geração de empregos vis a vis com o aumento da produtividade. Sobre esta abordagem, segundo Lo (2020, p. 830 $)^{27}$ :

Succinctly, in terms of economic development, the model has simultaneously achieved the following, all on unprecedented scales, particularly since the turn of the century: rapid expansion in both investment and consumption, rapid rises in both productivity and the wage rate, and rapid increases in job creation. All these have provided the necessary material conditions for broader social development: the fundamental enhancement of the power of labor, the reconstruction of a publicly-funded comprehensive healthcare system, and the acceleration of the process of urbanization. The relative efficiency of SOEs, and the functionality and credibility of their institutions, should all be assessed in conjunction with these developments

A tabela 1 demonstra que melhoria das condições de vida da população em concomitância com o rápido crescimento e investimento é sugestiva quando se

\footnotetext{
27 Tradução: Em suma, em termos de desenvolvimento econômico, o modelo alcançou simultaneamente o seguinte, tudo em escalas sem precedentes, particularmente desde a virada do século: rápida expansão tanto do investimento quanto do consumo, rápido aumento da produtividade e da massa salarial e rápidos aumentos na criação de empregos. Tudo isso proporcionou as condições materiais necessárias para um desenvolvimento social mais amplo: a valorização fundamental da força de trabalho, a reconstrução de um sistema de saúde integral com financiamento público e a aceleração do processo de urbanização. A eficiência relativa das estatais e a funcionalidade e credibilidade de suas instituições devem ser avaliadas em conjunto com esses desenvolvimentos.
} 
percebe que a variável consumo também oscila de forma muito positiva, incluindo variação maior que o investimento desde 2012:

Tabela 1- Crescimento Real das Taxas de Consumo e Investimento (1978-2018 em $\%)$

\begin{tabular}{|c|c|c|}
\hline & CONSUMO & INVESTIMENTO \\
\hline $1978-2018$ & 8,7 & 10,4 \\
\hline $1978-2000$ & 8,2 & 9,2 \\
\hline $2000-2012$ & 10,1 & 15,0 \\
\hline $2012-2018$ & 7,9 & 6 \\
\hline
\end{tabular}

Fonte: Lo (2020)

Sobre a planificação da destruição criativa, um outro dado mais geral pode ser percebido no gráfico 1 onde aponta outro interessante movimento que corrobora a nossa hipótese: a geração de empregos ao invés de diminuir, na medida em que o crescimento economia tem refluído a patamares na casa dos $6 \%$ anuais, aumentou e tem-se estabilizado ao longo dos últimos anos em um patamar ligeiramente acima dos 13 milhões de empregos urbanos. Isso significa que a consolidação de uma dinâmica baseada na inovação tecnológica têm sido acompanhada pelo cuidado com seus custos sociais, sendo o principal deles o desemprego. Trata-se do aplicação dos dois sentidos estratégicos da razão.

Gráfico 1- Crescimento econômico (em \%) x Milhões de novos empregos urbanos (2009-2019)

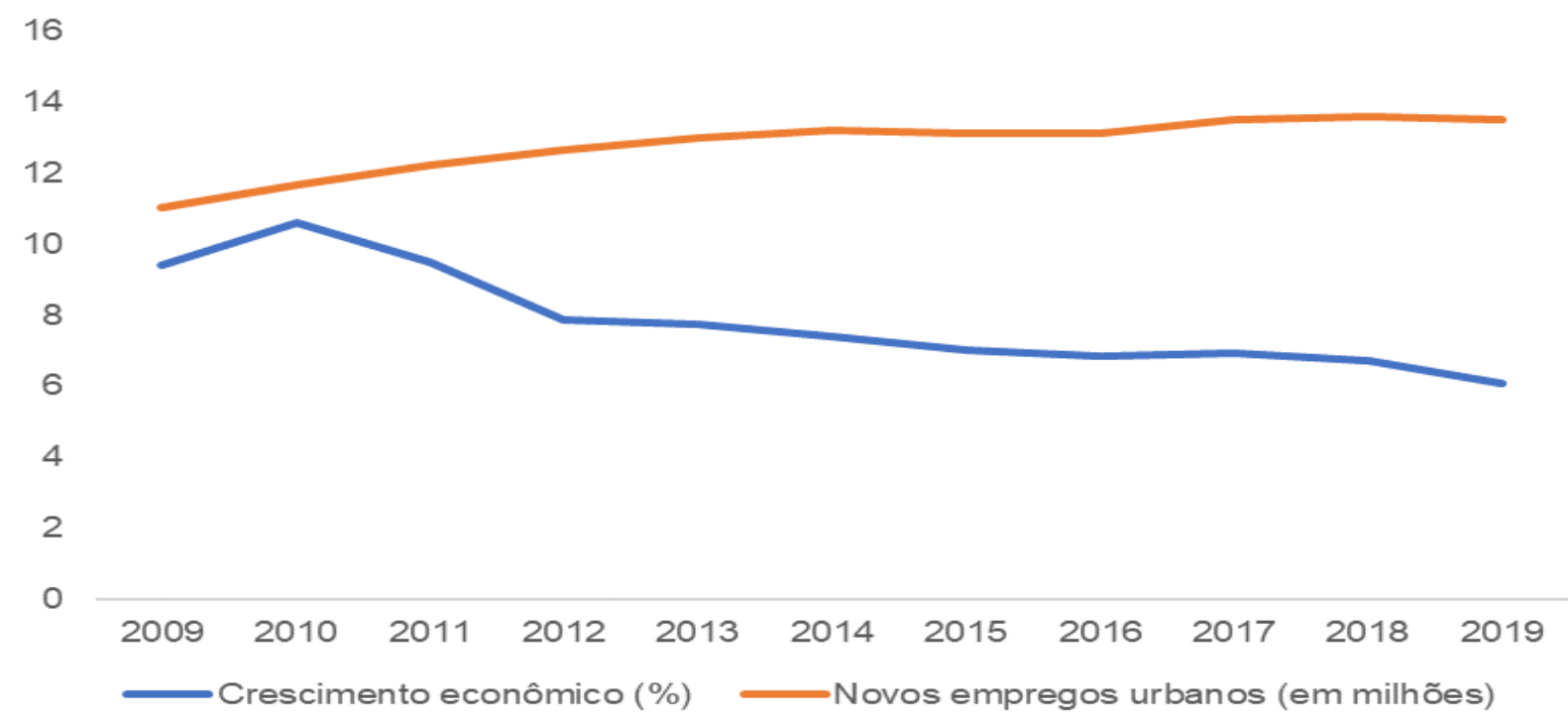

Fonte: NBS, 2019

Os gráficos 2 e 3 são mais incisivos em demonstrar dois intensos processos ocorridos em um curto espaço de tempo (dez anos) sintetizados tanto em aprofundamento da mudança estrutural na economia chinesa perceptível na rápida 
mudança na composição do emprego no país quanto em acentuada elevação da renda per capita.

Gráfico 2- Composição intersetorial do emprego na China - em milhões (20092018)

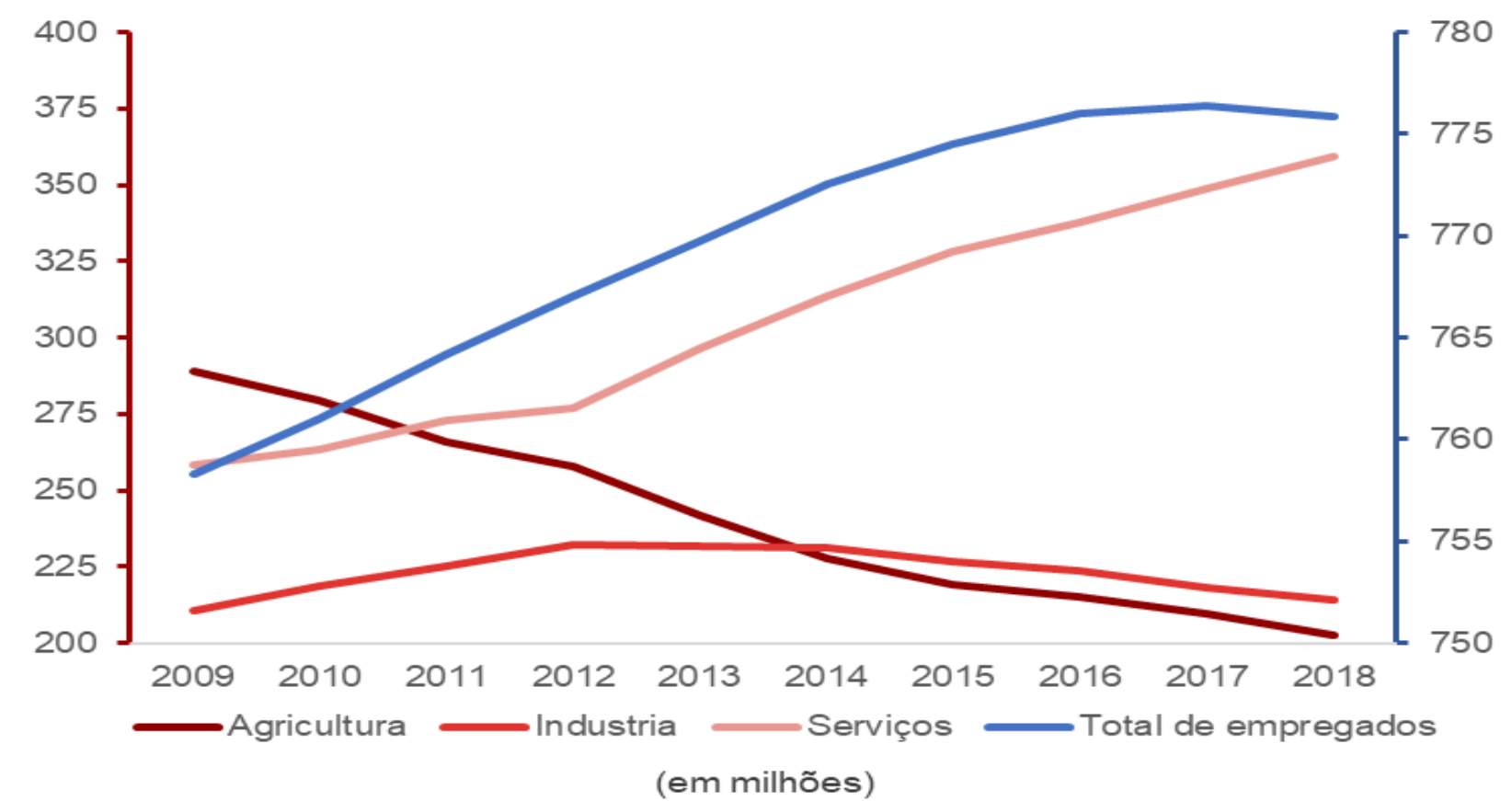

Fonte: NBS, 2019

O eixo da esquerda indica o número (em milhões) de empregados por setor, enquanto o eixo da direita indica o total de empregos no país. Traduzidos os dados gerais em milhões para porcentagem do total, dois destaques: estabilidade do emprego industrial que ficou entre $27,8 \%$ do total em 2009 e 27,6 em 2018. Por outro lado uma queda acentuada no emprego agrícola (de 38,1\% em 2009 para $26,1 \%$ do total em 2018) e elevação em ritmo inverso ao da agricultura no setor de serviços: era 34,1 em 2009, saltando para 46,3\% em 2018. Certamente o relaxamento do sistema Hukou de migração interna reserva explicação. Mas ao propósito de nosso trabalho, um dado fundamental: quase 100 milhões de pessoas foram transferidos de trabalhos agrícolas para trabalhos que vão desde a manufatura propriamente dita ${ }^{28}$, passando pela transformação de amplas parcelas da agricultura em ramos da indústria na divisão social do trabalho até a indústria da construção civil, até serviços tecnológicos, urbanos e (mesmo) rurais. Uma transformação desta profundidade e natureza não ocorre sem conflitos, sendo o mesmo seu motor primário. A grande questão é como isso está ocorrendo sem as

${ }^{28}$ A depender da instituição de pesquisa a chamada manufatura propriamente dita corresponde a algo em torno de 120 milhões de trabalhadores. No dado mais geral são computados os trabalhadores nos setor agroindustrial e construção civil. 
contrapartidas negativas tão comuns em outros países periféricos como o Brasil, Índia etc?

A planificação da destruição criativa é uma poderosa categoria explicativa, base fundamental desta "Nova Economia do Projetamento" que emerge na China. Eleva-se a divisão social do trabalho em todos os sentidos subsumindo a circunstância do desemprego via ação humana de planners e milhares de profissionais envolvidos em grandes projetos dos mais variados tipos e disposição

No que cerne ao nível de vida em geral da população chinesa, o que não significa que ocorrências como a desigualdade e a concentração de renda não estejam presentes naquela realidade - ao contrário ${ }^{29}$, a queda no crescimento econômico além de não incidir na redução no número de empregos gerados, não incorreu em queda no próprio crescimento da renda per capita. A renda per capita no ano de 2009 era de US\$ 3.812 e no ano de 2019 alcançou a cifra de US\$10.261 demonstrando acelerado, porém planificado processo de urbanização ${ }^{30}$ que em 2009 era de 47,88\% e em 2019 chegou a 60,3\%. Ou seja, nos últimos dez anos cerca de 150 milhões de chineses passaram a viver nas cidades.

Gráfico 3- Renda per capita em US\$ (2009-2019)

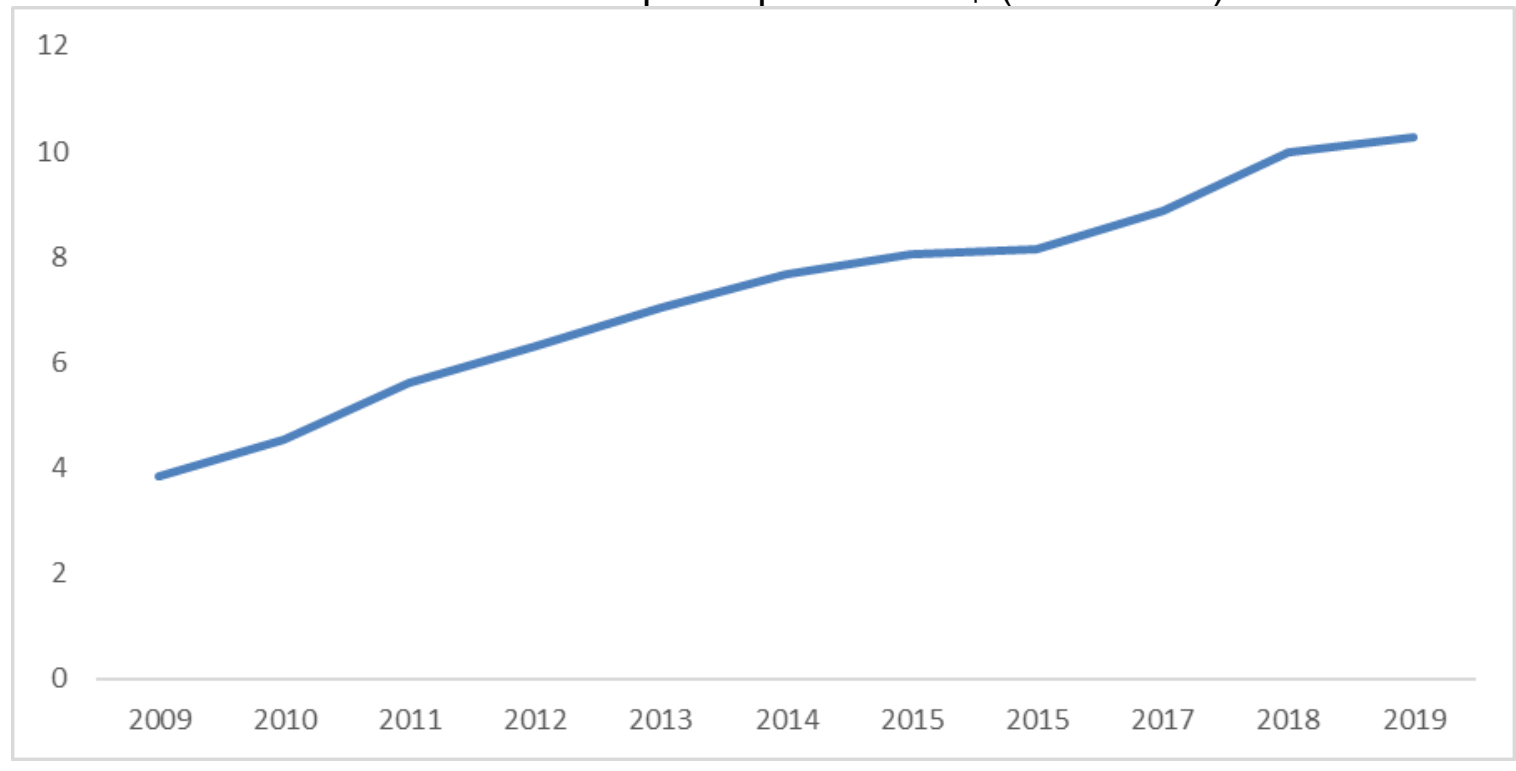

Fonte: World Bank, 2020

O "projetamento" neste caso é perceptível na capacidade de mediar uma planificação em larga escala em um curto espaço de tempo e minorando os conhecidos efeitos colaterais de um processo desta envergadura, incluindo negação do achatamento salarial. Neste caso, a figura 1 dá mais subsídios à compreensão da

\footnotetext{
${ }^{29}$ Sobre a dinâmica de distribuição na China em uma perspectiva comparada, ler Morais, Guimarães e Braga (2019).

30 Empregos urbanos são melhor remunerados, um dado óbvio.
} 
elevação da renda per capita pela via dos salários médios reais. Como se percebe entre 2008 e 2017 os salários médios reais na China dobraram.

Figura 1- Índice de salário real médio para países emergentes do G20, ano base: 2008 (2008-2017)

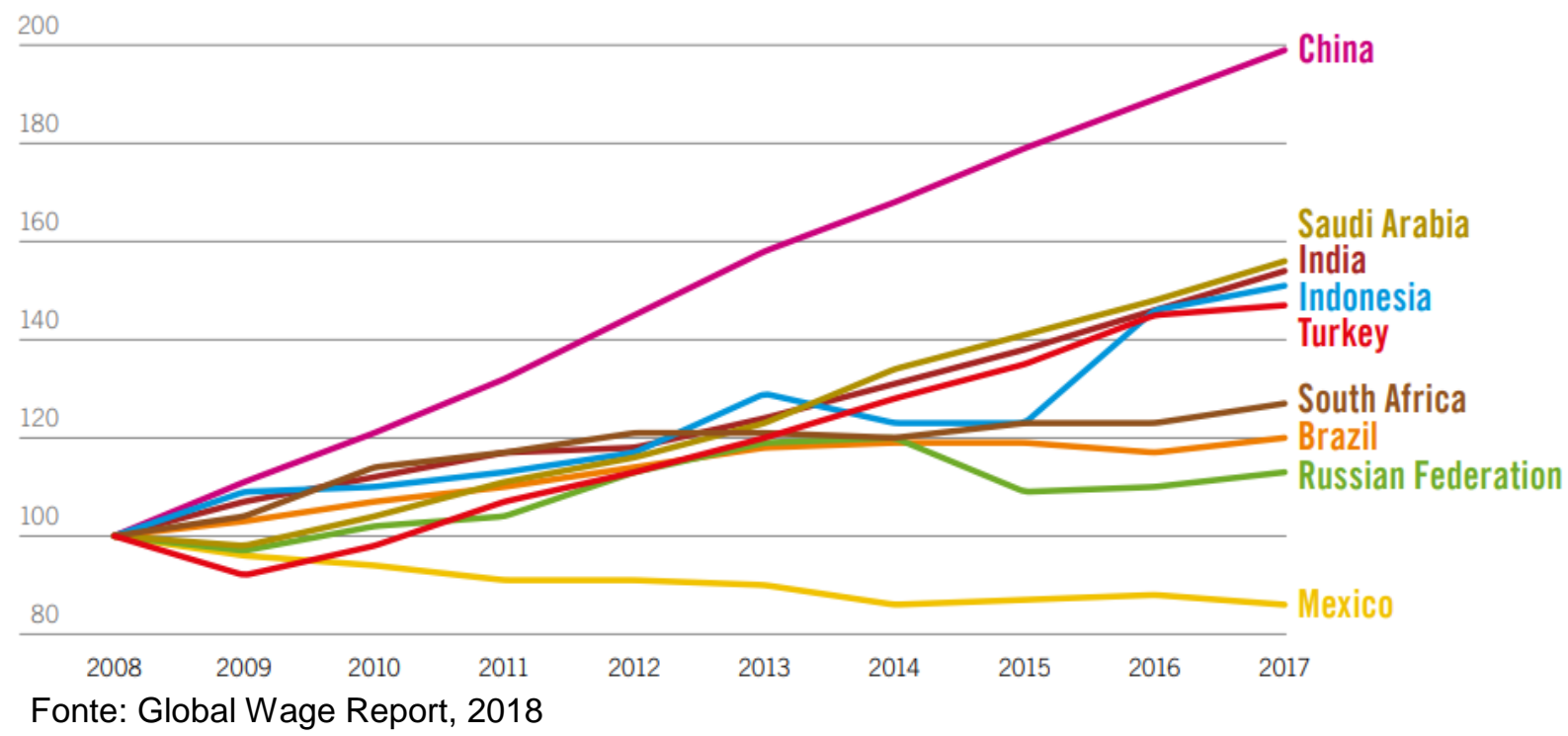

No que cerne as determinações relativas às possibilidades abertas de superação de incerteza keynesiana e a planificação da destruição criativa um longo caminho de pesquisas, cotejamento e observação de dados e processos há de ser percorrido. É promissor o caminho.

\subsection{O projetamento e a "soberania monetária"}

A "Economia do Projetamento" original, elaborada por Rangel no final da década de 1950, seria algo próximo de um modo de produção caracterizado - no fundamental - pela racionalização máxima do processo de produção cujo "projeto" serviria como um ente mediador entre a sociedade e o planejamento central. Essa relação entre plano e sociedade se daria pela utilização da razão tanto à criação de valores de uso/utilidade ao bem comum quanto à superação do desemprego enquanto circunstância. O primeiro ponto (criação de valores de uso/utilidade) é um processo histórico que envolve a criação de um poderoso setor produtivo capaz de gerar excedente a ser voltado à construção do setor improdutivo da economia. $\mathrm{O}$ segundo ponto, mais conjuntural, porém envolve questões de ordem política mais complexas, encerra-se na superação do desemprego enquanto circunstância. Nesse ponto a discussão sobre a papel da moeda é fundamental.

Assim sendo, o que comumente é chamada de soberania monetária passa a ser uma interface empírica que dá suporte ao conceito historicamente construído de 
"Economia do Projetamento". Alçada - ao lado da possibilidade da superação da incerteza keynesiana, da planificação da destruição criativa e do pacto tácito de adesão - ao grau de categoria, como já exposto, que dá sustentação empírica ao conceito. Definitivamente o uso funcional ou "projetado" da soberania monetária é um pré-requisito ao processo consciente/racional de desenvolvimento.

O socialismo, neste caso, seria a circunstância histórica sendo construída, por meio das interfaces entre suas diferentes formas históricas - a "Economia do Projetamento" apresenta-se como a forma histórica mais avançada do socialismo enquanto experiência real.

Segundo Deccache (2020), "O conceito de soberania monetária se mantém comoelemento central no debate da Teoria Monetária Moderna (Modern Money Theory, MMT)", um corpo teórico condensado por Wray (2003) para quem a moeda, como criação estatal ${ }^{31}$, poderá ser utilizada tanto como meio de estabilização de uma economia instável (Minsky, 1986) quanto ao objetivo de uma sociedade de funcionar em pleno emprego. Evidente que a busca primária por estabilidade monetária e de equilíbrio orçamentário como elementos ex ante a qualquer movimento a posteriori da economia não é nada funcional ao próprio funcionamento da própria economia e muito menos a sociedades que têm entre seus objetivos 0 pleno emprego humano e de fatores. Segundo Wray, sobre o papel da soberania monetária (2012, p. 194) 32 :

The idea is pretty simple. A government that issues its own currency has the fiscal and monetary space to spend enough to get the economy to full employment and to set interest rate target where it wants [...] For a sovereign nation, 'affordability' is not an issue; it spends by crediting bank accounts with its own IOUs, something it can never run out of. If there is unemployed labor, government can always afford to hire it, and by definition unemployed labor is willing to work for money.

No caso chinês, a dimensão cada vez maior dos pacotes de investimentos lançados ciclicamente, os grandes projetos que consomem centenas de bilhões de

\footnotetext{
31 Sobre a MMT, segundo Deos (2020): Considered by its founders as part of the Post-Keynesian school, MMT incorporates other theoretical lines within the heterodox field, such as the Institutionalists (Veblen), the Chartalists (Knapp, Innes), Functional Finances (Abba Lerner) and the Sectoral Balances (Wynne Godley). MMT stems from heterodox assumptions in order to: 1) describe the way capitalist economies work, with monetary and fiscal arrangements at its center; and to 2) prescribe public policies to avoid financial instability and ensure that full employment is achieved. Sobre a MMT ler, Wray (2003 e 2012); Deos (2020); Deccache (2020); Vergnhanini \& De Conti (2018).

32 Tradução: A ideia é muito simples. Um governo que emite sua própria moeda tem o espaço fiscal e monetário para gastar o suficiente para levar a economia ao pleno emprego e definir a meta de taxa de juros onde quiser [...] Para uma nação soberana, 'acessibilidade' não é um problema; ele gasta creditando contas bancárias com seus próprios IOUs, algo de que nunca pode ficar sem. Se houver trabalho desempregado, o governo sempre pode se dar ao luxo de contratá-lo e, por definição, o trabalho desempregado está disposto a trabalhar por dinheiro.
} 
yuanes $^{33}$ envolvendo desde imensas obras de infraestruturas até a busca da fronteira tecnológica ${ }^{34}$, são indícios que apontam a utilização consciente da moeda estatal para fins estratégicos por meio tanto da utilização deliberada de déficits públicos dos bancos de investimento - criadores de moeda por excelência - que passam a cumprir o papel minskyano de Big Bank dentro do contexto do Big Government (Minsky, 1986).

O primeiro elemento empírico a ser demonstrado neste espaço são os déficits públicos chineses. Vejamos seu comportamento desde 1983:

Gráfico 4- Défict público em \% do PIB (1983-2018)

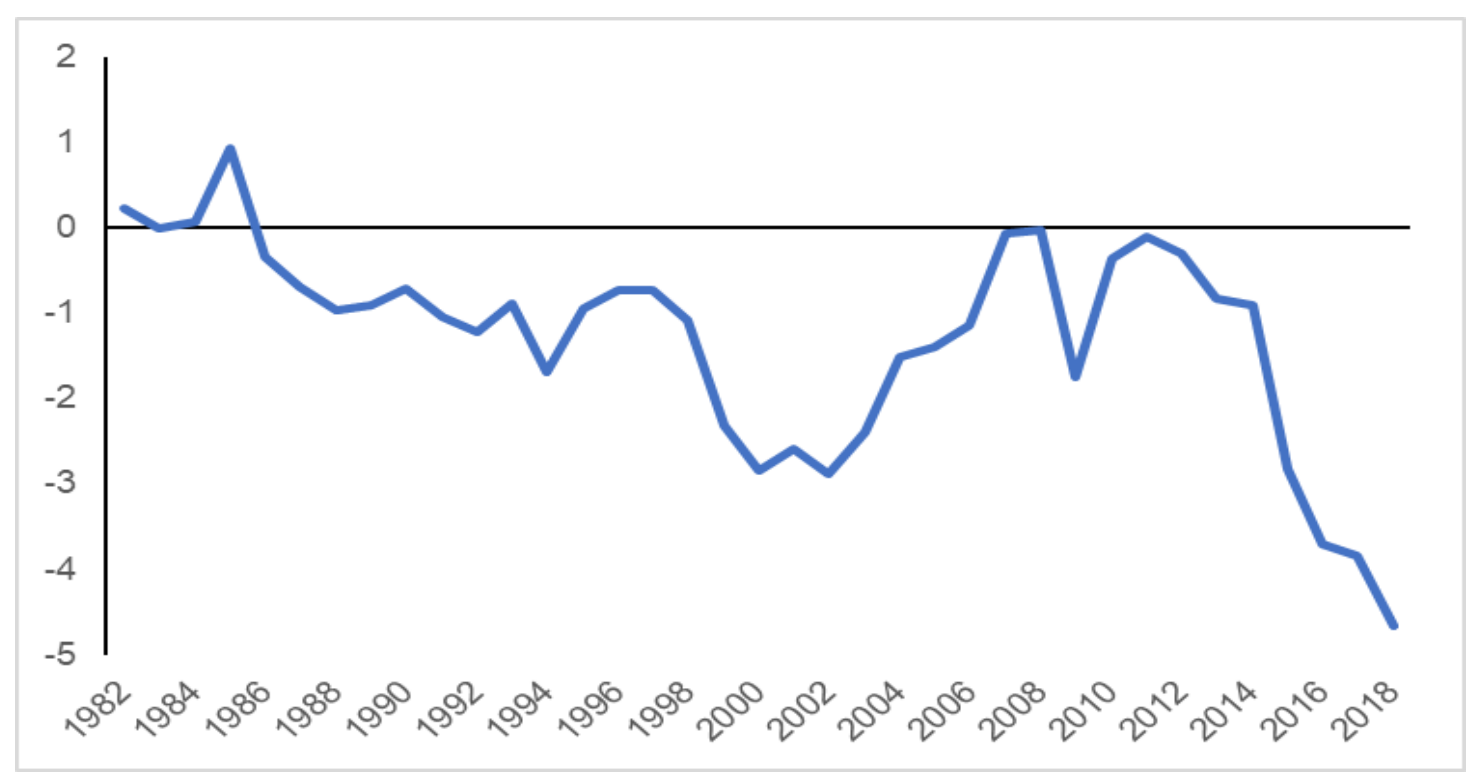

Fonte: NBS, 2019

A economia chinesa opera, literalmente, com déficits públicos desde o ano de 1986. As razões variam de acordo com a época e pode ir desde a emissão de dívidas para compor balanços das empresas estatais deficitárias antes da segunda metade dos anos de 1990, compra de ativos bancários podres como parte das

\footnotetext{
33 David Deccache nos alerta que a mobilização dos recursos reais em moeda doméstica é essencial para direcionar a produção interna para uma maior competitividade das exportações, atraindo uma massa maior de reservas em dólares, o que retroalimenta o circulo virtuoso ao relaxar as restrições externas, tão fortes em países periféricos com economias que tratam dos problemas relacionados à restrição externa com austeridade fiscal visando o equilíbrio do balanço de pagamentos pela redução da renda doméstica visando a queda das importações (o que aumenta a vulnerabilidade externa estrutural). A China segue o caminho oposto: tratou de eliminar as suas restrições tanto com boas políticas cambiais quanto com o direcionamento planejado da economia para a superação dos gargalos estruturais, algo impossível sem o bom uso da soberania monetária.

${ }^{34}$ Exemplos notáveis desta abordagem estatal podem ser percebidos, por exemplo, no pacote fiscal de US\$ 686 bilhões lançados em 2009 para conter os efeitos da crise financeira internacional, o projeto "Um Cinturão, Uma Rota" e o atual plano de US\$1,4 trilhão para superar seus grandes gargalos tecnológicos.
} 
várias reformas pelas quais passaram o sistema financeiro estatal até 0 financiamento a programas de financiamento direto a infraestruturas ${ }^{35}$.

Tendência interessante tem sido a do aprofundamento da utilização de déficits públicos desde 2011 quando o déficit foi de 0,01\% até alcançando a casa dos $-4,66 \%$ em 2018. Programas de desonerações tributárias maciças, anuncios de pacotes de investimentos em trens de alta velocidade e de busca da fronteira tecnológica nos mais diversos setores tem sido uma constante, principalmente nos últimos cinco anos e, de forma mais aguda, desde o início da guerra comercial e tecnológica por parte dos EUA, exigindo maior esforço fiscal diante das necessidades em torno da aceleração da busca do país por mais autonomia tecnológica em relação aos EUA.

O exercício consciente da soberania monetária para fins estratégicos encontra eco também no papel criador de moeda estatal por parte do sistema financeiro. O caso chinês, onde o sistema financeiro é dominados por uma malha de bancos de desenvolvimento estatais, este instrumento é fundamental ao desenvolvimento do país e criação de condições ao pleno emprego ${ }^{36}$. O gráfico 5 é sugestivo quanto ao papel fundamental cumprido por este instrumento ao processo de desenvolvimento chinês.

Gráfico 5- Crédito interno às empresas em \% do PIB (1977-2019)

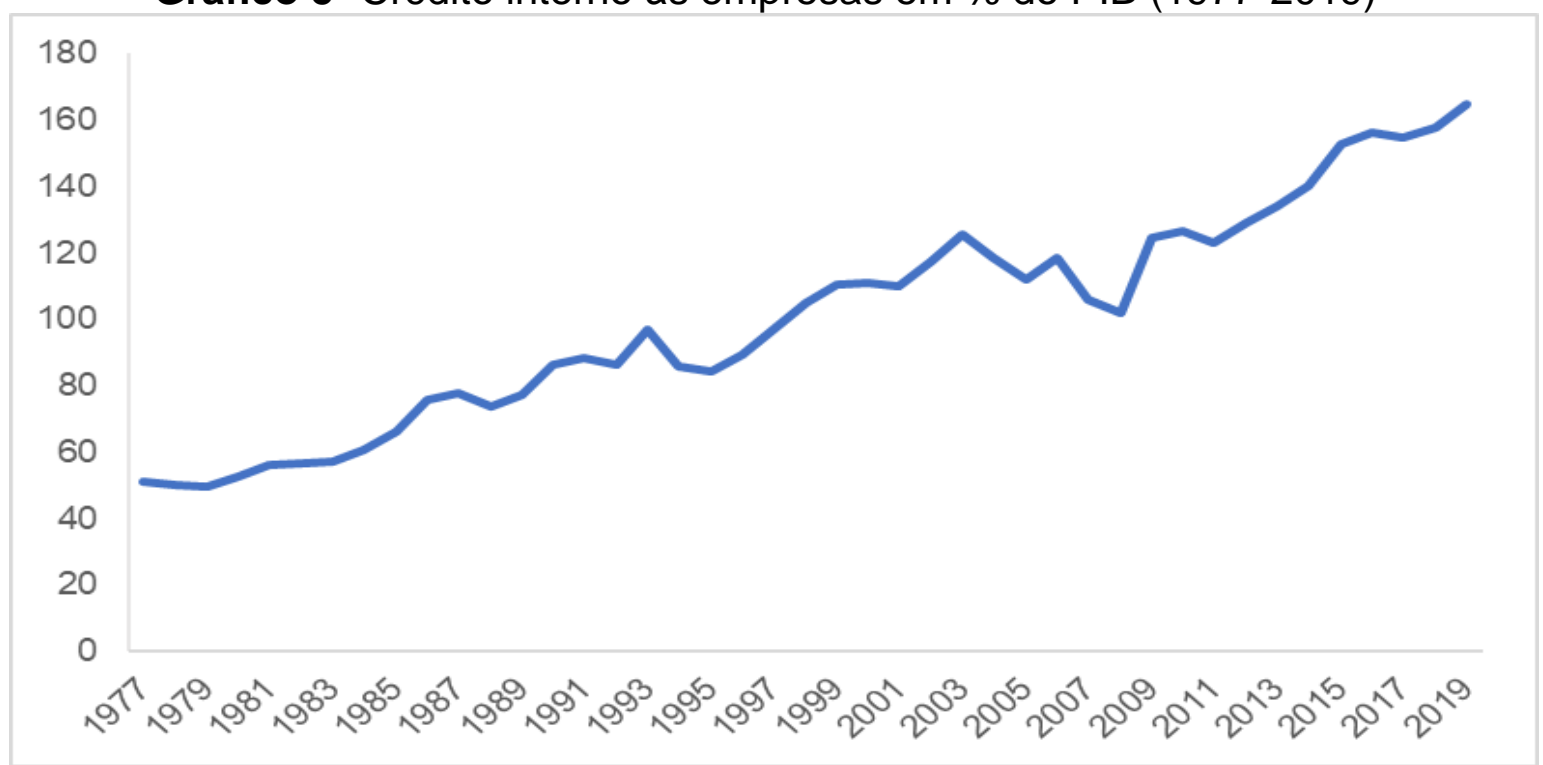

Fonte: World Bank, 2020

\footnotetext{
35 Fundamental dois dados à compreensão do processo. A China mantém fechada sua conta de capitais, acumula grandes superávits em transações correntes de forma ininterrupta desde 1994 e suas reservas cambais, as maiores do mundo, acima dos US\$ 3 trilhões garante perene condição de ter uma economia operando sem nenhuma grande restrição ao seu desenvolvimento.

${ }^{36}$ Sobre o sistema financeiro chinês ler Liang (2012), Burlamaqui (2015) e Cintra \& Silva Filho (2015).
} 
O papel do crédito na sustentação do esforço nacional chinês é latente na medida em que as reformas econômicas desembocam na formação de uma economia monetária de produção na metade da década de 1990. Enquanto os sistemas financeiros em geral têm se transformado em nascedouros de crises econômicas, o sistema financeiro chinês tem permanecido incólume desarranjos financeiros internacionais. Estímulos fiscais e monetários foram amplamente utilizados, por exemplo, ao enfrentamento da crise financeira internacional de 2008, por exemplo. Segundo Liang (2012, p. 14) ${ }^{37}$ :

The government's fiscal stimulus and monetary easing contributed greatly to the rapid recovery (...). The stimulus is centered on infrastructure spending, combined with increases in transfers, consumer subsidies, and tax cuts. State-owned commercial banks responded actively to the government's call and extended credit to finance infrastructure and other government-led projects. (...). Half of the new lending was channeled into infrastructure projects, while lending to manufacturers, real estate, and other sectors also soared by over 100 percent. In a nutshell, a state-dominated banking system generates and distributes liquidity in a very effective and timely fashion.

O crédito estatal às empresas não tem parado de crescer desde o início da presente década. Em 2011 estava na casa dos 123,09\% do PIB. Cresce desde então de forma acelerada desde então alcançando em 2019 o pico 164,66\% do PIB. Uma linha direta pode ser traçada entre todas as demandas políticas e geopolíticas apresentadas ao Estado chinês nos últimos anos e os resultados em matéria de geração de emprego e renda já expostos neste artigo. Definitivamente a soberania monetária é parte do cabedal categorial que sustenta a "Nova Economia do Projetamento" enquanto conceito.

\subsection{O projetamento e o "pacto tácito de adesão"}

As reformas econômicas de 1978 podem ser apreendidas como uma decisão estratégica que a China tomou diante do mundo e de si mesma. Durante quase 30 anos a transformação estrutural da economia foi acompanhada da constituição de um país com níveis muito baixos de desigualdade social (Nogueira, 2019). O igualitarismo clássico camponês foi encarnado na governança do país sob a tutela de um líder camponês de corte igualitarista (Mao Tsétung). $O$ ato seguinte, a transformação - em 1978 - da nova dinâmica chinesa em uma nova classe de

37 Tradução: O estímulo fiscal do governo e a flexibilização monetária contribuíram muito para a rápida recuperação (...). O estímulo está centrado nos gastos com infraestrutura, combinados com aumentos nas transferências, subsídios ao consumidor e cortes de impostos. Os bancos comerciais estatais responderam ativamente ao apelo do governo e concederam crédito para financiar a infraestrutura e outros projetos liderados pelo governo. (...). Metade dos novos empréstimos foi canalizada para projetos de infraestrutura, enquanto os empréstimos para fabricantes, imóveis e outros setores também dispararam mais de 100\%. Em suma, um sistema bancário dominado pelo Estado gera e distribui liquidez de maneira muito eficaz e oportuna. 
formações econômico-sociais onde a presença do mercado, do capital estrangeiro e do modo de produção capitalista em seu interior engendrou o aparecimento de novas relações sociais e, por conseguinte, de uma nova gama de sociabilidades.

O fetiche da mercadoria, o individualismo, o consumismo, a ocidentalização, a precarização do trabalho como tendência a ser enfrentada e a concorrência individual passaram a fazer parte do horizonte espiritual chinês em amplo confronto, em andamento e com imprevisíveis resultados, aos princípios socializantes e igualitários que marcam aquela trajetória histórica. Desigualdades sociais aprofundadas na década de 1990 aprofundaram um quadro contraditório e capaz de colocar em xeque a legitimidade do regime. Neste aspecto, que inclui crescente pressão e cerco imperialista, podemos dizer que a China é uma formação social em disputa. Em certa medida, uma unidade de contrários com síntese em processamento.

A Nova Economia do Projetamento seria uma resposta histórica aos desequilíbrios surgidos em quatro décadas de reformas econômicas. É linha de continuidade com as orientações intrínsecas às políticas - surgidas desde o mandato de $\mathrm{Hu}$ Jintao - de minoração das desigualdades sociais e regionais e de busca de conformação de um estado de bem-estar social com características chinesas $^{38}$. O empoderamento do setor estatal da economia e a elevação da capacidade do Estado em planificar em níveis superiores levou a uma reversão da tendência de aumento da desigualdade. Camponeses e nova classe operária urbana transformaram-se em elos-chave na pressão sobre o regime no rumo do enfrentamento de questões sociais candentes ${ }^{39}$. A contrapartida estatal às pressões populares pode ser percebida em inúmeras iniciativas, entre tais a transformação da legislação trabalhista em instrumento de inclusão das massas no mercado consumidor.

Evidente que, por outro lado, melhoras substanciais nos padrões de vida do povo, elevação do poderio nacional e a instituição de mega-projetos voltados ao bem estar da sociedade em geral tem sua contraparte subjetiva no que passamos a chamar de "pacto tácito de adesão". Pinheiro-Machado (2017, p. 123) substancia muito bem este estado subjetivo:

\footnotetext{
${ }^{38}$ Sobre a conformação deste estado de bem-estar social, ler Shaoguang (2014) e Nogueira, Bacil \& Guimarães (2020).

39 Segundo Pinheiro-Machado (2018, p. 122), "Ocorrem anualmente, por ano, cerca de 3 mil greves e de 100 mil a 200 mil protestos na China".
} 
Os chineses "comuns" percebem que rumo e prosperidade andam de mãos dadas na construção de um projeto de nação de longo prazo. Criticam a corrupção, reinvindicam reformas, mas também ressaltam o extraordinário feito de 800 milhões de pessoas terem sido removidas da pobreza. O governo é fixado em lançar projetos monumentais e audaciosos que visam a fornecer linhas de ação estratégica com metas temporais (...). O governo produz, assim, o tecnonacionalismo, incentivando a adesão popular a sua grande narrativa e seu projeto nacional.

$\mathrm{Na}$ verdade o nacionalismo continua sendo a grande narrativa de nosso tempo. Parte da percepção humana de si mesma ao longo de sua trajetória maternal de humanismo ${ }^{40}$. Neste tocante a contraparte às sociabilidades nocivas de mercado tem expressão no Partido Comunista da China (PCCh) no papel de elemento consciente da nação e da formação cultural, social; reservatório de ideias avançadas em relação ao capitalismo hegemônico em âmbito mundial. Nesta "unidade de contrários com síntese em processamento" o elemento da totalidade em movimento aponta a uma forte sociabilidade que combina nacionalismo, valores coletivistas/socialistas e internacionalismo ativo na conformação de marcos institucionais e de relações entre diferentes países de novo tipo, avançadas.

No caso da prontidão nacional com o PCCh levando 450 mil voluntários para combater a morte em Wuhan e o Estado que priorizou vidas em detrimento do lucro empresarial foi a cabal demonstração de que novos marcos de sociabilidade operam sobre o concreto. O "pacto tácito de adesão" fez-se sentir, suplantando as sociabilidades de formações econômico-sociais capitalistas e ocidentais, pela via da ressurgimento de vozes de Estado proclamando uma "Guerra Popular" contra o vírus. Interessante notar que sociedades baseadas por valores individualistas, consumistas e regidas pelo fetiche da mercadoria estão sendo facilmente batidas pela pandemia (Estados Unidos, Brasil, Reino Unido etc).

Lo e Shi (2020) fazem interessante análise comparativa entre China e Estados Unidos no combate à pandemia baseada nos conceitos de saída, voz e lealdade desenvolvidos em famoso livro de Hirschman (1970). Segundo os autores, que tratam o caso chinês como um "tough model" e os EUA como "loose model"41:

\footnotetext{
40 Neste sentido temos pleno acordo com Rangel (1960 [2005], p. 450): "A nação é, sem dúvida, uma categoria histórica, uma estrutura que nasce e morre, depois de cumprida sua missão. Não tenho dúvida de que todos os povos da Terra caminham para uma comunidade única, para 'Um Mundo Só'. Isto virá por si mesmo, à medida que os problemas que não comportem solução dentro dos marcos nacionais se tornem predominantes e sejam resolvidos os graves problemas suscetíveis de solução dentro dos marcos nacionais. Mas não antes disso. O 'Mundo Só' não pode ser um conglomerado heterogêneo de povos ricos e de povos miseráveis, cultos e ignorantes, hígidos e doentes, fortes e fracos"

41 Tradução: Em termos da relação Estado-Povo, o governo ouviu e respondeu à "voz" das bases e o "modelo duro" da China não descarta a possibilidade de autoaperfeiçoamento. Portanto, um ciclo virtuoso entre o Estado e as pessoas se formou posteriormente. Surpreendentemente, o "modelo
} 
In terms of the state-people relationship, the government listened and responded to the "voice" from the grassroots and China's "tough model" does not rule out the possibility of self-improvement. Therefore, a virtuous cycle between the state and people has formed afterwards. Surprisingly, the "loose model" tolerates the federal government's ignorance of people's voices, damaging the long-term co-operative relationship between the state and people, leading to a vicious cycle. This outcome subverts the long-existing framework of authoritarianism versus democracy in the literature

Transparece o "pacto tácito de adesão" justamente em um momento-limite do próprio socialismo enquanto forma histórica em estado embrionário. Ainda no plano externo, os movimentos recentes chineses como o "Um Cinturão, Uma Rota", indicam a projeção e alcance internacional da Nova Economia do Projetamento sob a forma de execução e financiamento de dezenas de milhares de projetos em infraestruturas em todos os quadrantes do mundo - como contraponto progressista à financeirização e barbárie que acomete o mundo ocidental. "Projetamento" neste caso seria expressão de uma moderna geopolítica popular, uma geopolítica anticolonialista e de libertação nacional (Silva, 2018) que tanto interessou a intelectuais da estatura tanto de Ignacio Rangel ${ }^{42}$ quanto Domenico Losurdo ${ }^{43}$.

A Nova Economia do Projetamento é apenas a ponta de um longo iceberg a provar que a história está longe do fim.

\section{Considerações finais}

Neste artigo pudemos avançar ao menos mais um passo na agenda de pesquisa do que convencionamos chamar de Nova Economia do Projetamento. A grande questão enfrentada, o que não significa a não necessidade de continuidade, foi a de encontrar novas determinações que tornasse possível a construção de um arcabouço de categorias, enquanto elos empíricos, do conceito em questão. A linha de raciocínio em torno do projetamento enquanto elevação do papel da razão sobre o processo de produção mostrou-se fundamental na mesma medida em que uma série de dados foram expostos compondo elementos de validação teórica à nossa hipótese.

Nesta aproximação com o conceito em questão foram quatro as categorias expostas: 1) a possibilidade de superação da incerteza keynesiana pari passu com

frouxo" tolera a ignorância do governo federal sobre as vozes das pessoas, prejudicando a relação cooperativa de longo prazo entre o Estado e o povo, levando a um ciclo vicioso. Este resultado subverte à abordagem antiga baseada na dicotomia autoritarismo versus democracia na literatura

42 Rangel (1952)

43 Losurdo (2004) 
2) a planificação da "destruição criativa"; 3) a utilização consciente da soberania monetária e 4) o "pacto tácito de adesão". Cada uma dessas categorias surgem como espelho do que Rangel colocava como "os dois sentidos estratégicos da razão" encerrados na superação do desemprego enquanto circunstância e a programação de novos desequilíbrios pela introdução de novas tecnologias. Demonstramos com dados empíricos a possibilidade de aplicação deste conceito original de Ignacio Rangel abrindo possibilidade para novos aportes teóricos capazes explicar, no conjunto, o fenômeno chinês.

O sentimento de repensar um cabedal conceitual e categorial capaz de explicar um fenômeno complexo e em rápido movimento nos faz sentir que estarmos dentro de um grande processo, e o mais importante: tomando consciência do mesmo, é tão singular quanto emocionante. Estarmos fazendo isso sob uma perspectiva conceitua produzida no Brasil é também pensar possibilidades de desenvolvimento à nossa própria nação. O fenômeno chinês, longe de ser um "modelo" aponta a regularidades que podem ser tratadas como universais, a começar pelo papel do Estado e sua evolução ao longo do tempo até a tomada completa da razão enquanto instrumento de governo e agente de políticas onde a humanidade esteja em prioridade em relação ao lucro empresarial e em processo de desacoplameto de expressões e sociabilidades de formas e modos de produção pretéritos.

Sobre o processo que envolve a própria Revolução Chinesa em si, a Nova Economia do Projetamento deve ser percebida como parte de um experimento que, segundo Silva (2018) e Losurdo (2018) demarca-se como exemplo de uma processo de construção do socialismo que tem tido a sabedoria de se apartar de messianismos caros ao movimento comunista internacional para assim se posicionar diante da própria história (a Revolução Cultural, o Grande Salto à Frente) e da história do movimento comunista internacional (a dificuldade de organizar um Estado socialista de direito na ex-URSS) com as exigências da crítica como forma de angariar legitimidade. Um processo capaz de conceber o desenvolvimento histórico com rigor dialético, convidando a pensar a negação e a derrubada da ordem existente como simultânea herança dos pontos mais altos do ordenamento político e social negado e derrubado.

É assim que historicamente posicionamos a Nova Economia do Projetamento no campo do pensamento e da prática marxistas mais avançadas de nosso tempo presente. Esse estágio superior do modo de produção dominante à nova formação 
econômico-social que emerge na China é o ponto zero explicativo das razões do anunciado "Chernobyl chinês" ter se tornado a sua antítese, o "momento Suptnik" da ainda jovem República Popular.

\section{REFERÊNCIAS}

BURLAMAQUI, L. Finance, development and the Chinese entrepreneurial state: A Schumpeter-Keynes-Minsky approach. Brazilian Review of Political Economy, v. 4, n. 141, p. 728- 744, 2015.

CARVALHO, F. C. Keynes on Expectations, Uncertainty and Defensive Behavior. Brazilian Keynesian Review. v. 1, n.1, 2015.

CASTRO, M. H. "Elementos de economia do projetamento". In, HOLANDA, F, M.; ALMADA, J. e PAULA, Z. A. Ignácio Rangel, decifrador do Brasil. São Luís: Edufma, 2014.

CHENG, S. Primitive Socialist Accumulation in China: An Alternative View on the Anomalies of Chinese "Capitalism". Radical Review of Political Economics. May 2020.

CINTRA; SILVA FILHO (2015). "O Sistema Financeiro Chinês: A Grande Muralha”. In China em Transformação. Brasília: IPEA, 2015.

DEOS, S. Modern Money Theory: Rise in the International Scenario and Recent Debate in Brazil. No prelo, 2020.

DECCACHE, D. "Soberania monetária, regimes cambais e política econômica". In, DALTO, F.; GERIONI, E.; OZZIMOLO, J.; DECCACHE, D.; CONCEIÇÃO, D. Teoria Monetária Moderna: a chave para uma economia a serviço das pessoas. Fortaleza: Remo Bastos, 2016.

GABRIELE, A. Enterprises, Industry and Innovation in the People's Republic of China Questioning Socialism from Deng to the Trade and Tech War. Munchen: Springer, 2020.

HEGEL, G. W. Cursos de Estética. Vol. 3. São Paulo: Edusp, 1905 [2001].

HIRSCHMAN, Albert. The Strategy of Economic Development. New Haven: Yale University Press, 1958.

HIRSCHMAN, A. Exit, Voice, and Loyalty: Responses to Decline in Firms, Organizations, and States. Cambridge, Massachusetts: Harvard University Press, 1970.

INTERNATIONAL LABOUR ORGANIZATION. Global Wage Report 2018/19 - What lies behind gender pay gaps. Geneva: ILO, 2018.

JABBOUR, E.; DANTAS, A.; ESPÍNDOLA, C. "Considerações iniciais sobre a "Nova Economia do Projetamento'. Geosul. v. 35, n. 75, p. 17-42, 2020.

JABBOUR; DANTAS, A. "The political economy of reforms and the present Chinese Transition". Brazilian Journal of Political Economy, v. 37, n. 4, p. 789-807, 2017.

JABBOUR E.; DANTAS, A. "Na China emerge uma Nova Formação Econômico-Socia". Princípios, oㅜ 154, p.70-86, 2018.

JABBOUR, E; \& PAULA, L. F. Socialization of Investment and Institutional Changes in China: A Heterodoxy Approach. Forum for Social Economics, 2020. 
JESPERSEN, J. Post-Keynesian economics: uncertainty, effective demand \& (un)sustainable development. Paper presented at the AEH-conference, London, 9-12 July, 2009.

KALECKI, M. Political Aspects of Full Employment. Political Quaterly, 1943.

LARDY, N. The State Strikes Back: The End of Economic Reform in China? Washington: Peterson Institute for International Economics, 2018.

LIANG Y (2012) Development Finance, The Chinese Economy, v. 45, n.1, p. 8-27.

LO, D.; SHI, Y. China versus the US in the Pandemic Crisis: The State-People Nexus Confronting Systemic Challenges. SOAS Department of Economics. Working Paper No. 237, London: SOAS University of London, 2020.

LO, D. State-Owned Enterprises in Chinese Economic Transformation: Institutional Functionality and Credibility in Alternative Perspectives. Journal of Economic Issues, v. 54, n. 3, pp. 813- 83, 2020.

LOSURDO, D. O marxismo ocidental - como nasceu, cmo morreu, como pode renascer. São Paulo: Boitempo, 2018.

LOSURDO, D. Fuga da história - A revolução russa e chinesa vista de hoje. Rio de Janeiro: Revan, 2004.

MARX, K. Critica ao Programa de Gotha. São Paulo: Boitempo, [1871] 2012.

PINHEIRO-MACHADO, R. "Posfácio: rumo e depressão". In, ANDERSON, P. Duas revoluções. São Paulo: Boitempo, 2018.

MAZZUCATO, M. O Estado Empreendedor: desmascarando o mitodo setor público $\mathrm{x}$ setor privado. São Paulo: Portfolio-Penguim, 2014.

NATIONAL BUREAU OF STATISTICS OF CHINA. China Statistical Yerarbook, 2019. Disponível em: http://www.stats.gov.cn/tjsj/ndsj/2019/indexeh.htm Acessado a 22/08/2020.

NAUGHTON, B.: Is China socialist? Journal of Economic Perspectives, v. 31, n. 1, p. 3-24, 2017.NOGUEIRA, I. Industrialização, Distribuição e Estratégia: Legados do maoísmo para a trajetória de desenvolvimento econômico da China. Carta Internacional, v. 14, n. 2, pp. 2751, 2019.

NOGUEIRA, I.; GUIMARÃES, J.: BRAGA, J. Inequalities and capital accumulation in China. Brazilian Journal of Political Economy, v. 39, n. 3, p. 449-469, 2019.

NOGUEIRA, I; BACIL, F.; GUIMARÃES, J. A caminho de um estado de bem-estar social na China? Uma análise a partir dos sistemas de saúde e de educação. Economia e Sociedade. v. 29 , n. 2 (69), p. 669-692, 2020.

PIKETTY, T; YANG, L.; ZUCMAN, G. Capital accumulation, private property and rising inequality in China. NBER Working Paper, n. 23368, Apr. 2017.

RANGEL, I. Prossegue a recuperação chinesa. Cadernos do Nosso Tempo. v. 1, n 1, p. 5964, 1952.

RANGEL, I. "Desenvolvimento e Projeto". In, RANGEL, I.: Obras Reunidas. Rio de Janeiro: Contraponto, [1956] 2005. 
RANGEL, I. "Elementos de Economia do Projetamento". In, RANGEL, I.: Obras Reunidas. Rio de Janeiro: Contraponto, [1959] 2005.

RANGEL, I. "Recursos ociosos e política econômica". In, RANGEL, I.: Obras Reunidas. Rio de Janeiro: Contraponto, [1960] 2005.

RODRIK, D. China As Economic Bogeyman. The Asian Post. 10/07/2020. Disponível em: https://theaseanpost.com/article/china-economic-bogeyman Acessado a 20/07/2020.

SHAOGUANG, W. Toward Shared Prosperity: China's New Leap Forward in Social Protection. Economic and Political Studies. v. 2, n, 1, p. 161-196, 2014.

SILVA, M. A. Domenico Losurdo, filósofo da história, geógrafo do anticolonialismo. Portal Grabois. 16/07/2018. Disponível em: http://www.grabois.org.br/portal/artigos/154501/201807-16/domenico-losurdo-filosofo-da-historia-geografo-do-anticolonialismo Acessado a 13/09/2020.

STOHS, M. H. 'Uncertainty' in Keynes' General Theory. History of Political Economy. v. 12, n. 3, p.372-382, 1980.

VERGNHANINI, R.; DE CONTI, B. Modern Monetary Theory: a criticism from the periphery. Brazilian Keynesian Review, v. 3, n 2, p. 16-31, 2018.

WORLD BANK. GDP per capita. World Development Indicators. Disponível em: https://data.worldbank.org/indicator/NY.GDP.PCAP.CD Acessado a 14/08/2020.

WORLD BANK. Domestic credit to private sector (\%GDP). World Development Indicators. Disponível em: https://data.worldbank.org/indicator/FS.AST.PRVT.GD.ZS Acessado a 15/08/2020.

WRAY, L. R. Trabalho e moeda hoje: A chave para o pleno emprego e a estabilidade dos preços. Rio de Janeiro: UFRJ/ Contraponto, 2003.

WRAY, L. R. (2012) Modern Money Theory: A Primer on Macroeconomics for Sovereign Monetary Systems. London: Palgrave Macmillan, 2012.

ZHAN, S. The land question in in 21ST in China. Monthly.

\section{NOTAS DE AUTOR}

\section{CONTRIBUIÇÃO DE AUTORIA}

Elias Marco Khalil Jabbour - Concepção. Coleta de dados, Análise de dados, Elaboração do manuscrito, revisão e aprovação da versão final do trabalho

Alexis Toribio Dantas - Concepção e elaboração do manuscrito. Coleta de dados Participação ativa da discussão dos resultados; Revisão e aprovação da versão final do trabalho.

Carlos José Espíndola - Concepção e elaboração do manuscrito. Coleta de dados Participação ativa da discussão dos resultados; Revisão e aprovação da versão final do trabalho.

Júlio Vellozo - Concepção e elaboração do manuscrito. Coleta de dados Participação ativa da discussão dos resultados; Revisão e aprovação da versão final do trabalho 


\section{CONSENTIMENTO DE USO DE IMAGEM}

Não se aplica.

\section{APROVAÇÃO DE COMITÊ DE ÉTICA EM PESQUISA}

Não se aplica.

CONFLITO DE INTERESSES

Não se aplica.

\section{LICENÇA DE USO}

Este artigo está licenciado sob a Licença Creative Commons CC-BY. Com essa licença você pode compartilhar, adaptar, criar para qualquer fim, desde que atribua a autoria da obra.

\section{HISTÓRICO}

Recebido em: 20-09-2020

Aprovado em: 13-10-2020 